\title{
A 3D Simulation of Single-Channel High-Temperature Polymer Exchange Membrane Fuel Cell Performances
}

\author{
Mohammad Yaghoub Abdollahzadeh Jamalabadi ${ }^{1,2, *}\left(\mathbb{D}\right.$, Milad Ghasemi $^{3}, \operatorname{Rezvan}_{\text {Alamian }}{ }^{4}{ }^{(}$, \\ Ebrahim Afshari ${ }^{5}$, Somchai Wongwises ${ }^{6,7}$, Mohammad Mehdi Rashidi ${ }^{8}$ \\ and Mostafa Safdari Shadloo 9 (D) \\ 1 Department for Management of Science and Technology Development, Ton Duc Thang University, \\ Ho Chi Minh City 700000, Vietnam \\ 2 Faculty of Civil Engineering, Ton Duc Thang University, Ho Chi Minh City 700000, Vietnam \\ 3 Faculty of Mechanical Engineering, Babol Noshirvani University of Technology, Babol 47148-71167, Iran \\ 4 Sea-Based Energy Research Group, Babol Noshirvani University of Technology, Babol 47148-71167, Iran \\ 5 Department of Mechanical Engineering, Faculty of Engineering, University of Isfahan, Hezar-Jerib Ave., \\ Isfahan 81746-73441, Iran \\ 6 Fluid Mechanics, Thermal Engineering and Multiphase Flow Research Lab. (FUTURE), Department of \\ Mechanical Engineering, Faculty of Engineering, King Mongkut's University of Technology Thonburi, \\ Bangmod, Bangkok 10140, Thailand \\ 7 The Academy of Science, The Royal Society of Thailand, Sanam Suea Pa, Dusit, Bangkok 10300, Thailand \\ 8 Shanghai Automotive Wind Tunnel Center, Tongji University, Shanghai 201804, China \\ 9 CORIA Lab./CNRS, University and INSA of Rouen, Normandie University, 76000 Rouen, France \\ * Correspondence: abdollahzadeh@tdtu.edu.vn
}

Received: 4 August 2019; Accepted: 30 August 2019; Published: 3 September 2019

\begin{abstract}
The fuel cell is an electrochemical energy converter that directly converts the chemical energy of the fuel into electrical current and heat. The fuel cell has been able to identify itself as a source of clean energy over the past few decades. In order to achieve the durability and stability of fuel cells, many parameters should be considered and evaluated Therefore, in this study, a single-channel high-temperature polymer exchange membrane fuel cell (HT-PEMFC) has been numerically simulated in three-dimensional, isothermal and single-phase approach. The distribution of the hydrogen and oxygen concentrations, as well as water in the anode and cathode, are shown; then the effect of different parameters of the operating pressure, the gas diffusion layer porosity, the electrical conductivity of the gas diffusion layer, the ionic conductivity of the membrane and the membrane thickness are investigated and evaluated on the fuel cell performance. The results showed that the pressure drop in the cathode channel was higher than the anode channel, so that the pressure drop in the cathode channel was higher than 9 bars but, in the anode channel was equal to 2 bars. By examining the species concentration, it was observed that their concentration at the entrance was higher and at the output was reduced due to participation in the reaction and consumption. Also, with increasing the operating pressure, the electrical conductivity of the gas diffusion layer and ionic conduction of the membrane, the performance of the fuel cell is improved.
\end{abstract}

Keywords: high-temperature PEM fuel cell; operating pressure; porosity coefficient; ionic conduction; electrical conductivity; fuel cell performance

\section{Introduction}

Due to the environmental issues posed by fossil energy sources, reducing the effects of these sources is one of the main priorities in energy planning today. In this context, in addition to striving 
for maximum energy savings, the most important concern is to replace these energy sources with renewable energies [1]. Consequently, the use of these resources such as fuel cell, wave [2,3], wind [4], solar, and hydrothermal energies attained substantial attention [5-7]. Fuel cells, especially PEM fuel cells with high power density, high efficiency, and short startup time are recognized as one of the most encouraging technologies for achieving these goals that can be employed in various applications [8-10].

Numerous research has been done recently for optimization of the PEM fuel cells performance considering various parameters that can be effective on its proficiency [11-15]. The operating temperature in determining the type of PEM fuel cells is an important parameter. In addition to operating temperature, the main difference between normal PEM fuel cell and high temperature is the membrane of the fuel cell. The normal polymer membrane is a Nafion ${ }^{\circledR}$ type that is made from perfluoro-carbon-sulfonic acid ionomer. The fuel entering the cell should be saturated with steam so that the membrane does not dry because the transfer mechanism uses the water as a proton carrier from the membrane. The function of the fuel cell at the desired temperature can lead to a blockage problem, which causes the membrane to flood and reduce the ionization of the membrane. Therefore, research was directed into the development of a new membrane so that it can function well above $100{ }^{\circ} \mathrm{C}$ and have a high conductivity in low moisture [16].

Improved membranes should have low material costs and high durability. Acid-based polymer membranes have been developed to achieve high proton conductivity, and one of the most favorite acid-base polymer membranes is polybenzimidazole (PBI) doped with phosphoric acid to increase the protonic conductivity. Phosphoric acid has more stability than other acids. In the context of the development of HT-PEMFCs, Authayanun et al. performed extensive studies and evaluated the results of one, two, and three-dimensional simulations in this area [16]. Studies have shown that most research has been done to examine the materials and processes for improving fuel cell performance, including optimizing and simplifying fuel cell components and simulation of fuel cell systems to diminish their cost and enhance the efficiency, stability and durability compared to combustion engines; these should be considered in the studies.

Rosly et al. [17] reviewed the research on various HT-PEMFCs and parameters affecting their performance. Based on their investigations, it is possible to find suitable solutions for increasing the stability and durability of the fuel cell and create proper conditions for better fuel cell performance. For this purpose, firstly, the components and performance of low-temperature fuel cell have been explored, and the need to go towards the design and development of high-temperature fuel cell components has been expressed in order to be able to achieve key factors in optimum fuel cell performance. Also, the effect of various parameters on the performance of PEMFC such as different working temperatures, working pressures, and combinations of these parameters was evaluated experimentally by Wang et al. [18]. Voltage-current diagrams obtained from experimental results have shown the effect of these variables on fuel cell performance. Graphs have revealed that fuel cell performance has improved with increasing fuel cell pressure and temperature due to increased fuel reaction rate. Furthermore, the simulation of a three-dimensional fuel cell model was implemented, and the results were compared with experimental work, which showed an acceptable match between experimental and numerical data. Subsequently, Cheddie and Munroe presented a one-dimensional mathematical model for predicting the performance of HT-PEMFC with PBI membrane [19]. Their attention was on MEA and evaluated the energy and mass transfer in the gas diffusion layer (GDL) and the electrochemical model. The most significant loss in the PBI fuel cell is the activation over-potential. The second-largest was Ohmic over-potential. The performance of this type of fuel cell has also been improved by increasing the membrane conductivity and enhancing catalyst performance.

Scott et al. [20] improved a high-temperature fuel cell with PBI membrane condensed by phosphoric acid in a one-dimensional and steady-state. In this research, the effect of operating pressure and cell temperature on the open circuit potential, and the effect of diffusion coefficients, exchange current density, and water transport across the membrane on the conductivity of the PBI membrane were examined. Their results are consistent with experimental data. Olapade et al. [21] studied the 
morphological properties of HT-PEMFC components by one-dimensional modeling, in steady-state and non-isothermal conditions, so that by achieving an optimal state, the catalyst layer can hold the steam generated from electrochemical reactions brought on by the feed gases. Their simulation was carried out at the temperature of $190^{\circ} \mathrm{C}$ and operating pressure of 2 bars. The results showed that the porosity reduction of the GDL leads to retaining more water in the catalyst layer. Also, they stated that the use of micro-porous layer also helps to keep water generated in the catalyst layer by reducing the pore size and porosity of the layer. It should be noted, however, that the pore size and porosity of the fuel cell components should not be too small to prevent the increasing of over-potential of oxygen concentration. Besides, the porosity reduction of the GDL causes the steam to rise in the catalyst layer. The optimal values of the GDL porosity and the micro- porous layer depend on factors such as cell voltage, operating pressure and relative humidity, which have been investigated and calculated in this paper.

Shamardina et al. [22] simulated two-dimensional HT-PEMFC and investigated the role of transport in the cathode catalyst layer. Their calculations showed that close to the oxygen channel inlet, the cathode catalyst layer works in the regime limited by poor proton transport, while close to the outlet, the cathode catalyst layer operation is specified by poor oxygen transport. Sue et al. [23] examined numerically and experimentally the performance of high-temperature fuel cell. In their numerical simulation, they used a two-dimensional model and observed the effect of PBI loading on the fuel cell. In their research, PBI value in the catalyst layer is considered between 5 to $30 \mathrm{wt} \%$, and cell temperature is considered in the range of $160-200{ }^{\circ} \mathrm{C}$. Sun et al. [24] numerically surveyed the effect of temperature and mass transfer in an HT-PEMFC. Their models were simulated in two-dimensional and single-phase models, and the effect of the porosity of the GDL and its thickness on the fuel cell performance were evaluated. The results show that increasing the cell temperature and the porosity of the GDL and reducing the thickness of the GDL will improve the performance of high-temperature fuel cells.

Using the PEM fuel cell simulation, Al-Baghdadi and Al-Janabi [25] studied and optimized the parameters affecting the performance of the fuel cell. Their models have a direct gas flow channel and are simulated three-dimensional, single-phase, and non-isothermal. They studied the effect of temperature, pressure, flow stoichiometry, gas channel width, thickness of the GDL, membrane thickness, porosity of the GDL and thermal conductivity of the GDL on the fuel cell performance. Zhang et al. [26] investigated the effect of relative humidity on the performance of single-cell PEM fuel cell at temperature of $120^{\circ} \mathrm{C}$ and pressure of 1 atmosphere. Their experimental results showed that with relative humidity decreasing from 100 to 25 percent, the voltage reached from $0.675 \mathrm{~V}$ to $0.358 \mathrm{~V}$ and the performance and production capacity of the fuel cell decreased, since, with decreasing of humidity, the electrode reaction and mass penetration rate were slower and membrane resistance increases. They indicated that by enhancing the relative humidity from 25 to 100 percent, the pressure drop in the anode and the cathode increases, and the partial pressure of oxygen and hydrogen decreases, which are a function of the input relative humidity at temperature of $120^{\circ} \mathrm{C}$ and pressure of 1 atmosphere. Ubong et al. [27] experimentally and numerically studied the performance of HT-PEMFCs. Their model is a single cell with a serpentine channel, and their simulation were implemented in steady-state, three-dimensional, and isothermal.

Su et al. [28] addressed the three-dimensional and isothermal simulation of an HT-PEMFC with PTFE membrane. They examined the parameters such as the distribution of saturated water, membrane conductivity, temperature, flow density, etc. on the performance of the fuel cell. Wang et al. [29] investigated the start-up process modeling of an HT-PEMFC using Comsol software. Starting HT-PEM fuel cells from room temperature to a proper operating temperature is a challenge. In this study, the preheated air was used to increase the temperature of the cooling channel or gas channel, and the optimum state was selected by checking the start-up time and temperature behavior of the fuel cell. Liu and Chang [30] experimentally investigated the effects of the micro-porous layer on the performance of an HT-PEMFC based on PBI. Using PBI electrolyte, they expressed the effect of MPL 
compounds, including PTFE and carbon and extracted an optimal state. The results showed that the micro-porous layer with a content of $40 \mathrm{wt} \%$ of PTEF and loading of $1 \mathrm{mg} / \mathrm{cm}^{2}$ carbon yielded the optimum performance of the cell. Lonescu [31] performed a three-dimensional simulation of a single-channel HT-PEMFC in a steady state. In this research, the Comsol software was used for simulation, and the concentration of species, namely, hydrogen and oxygen, and water concentration in the cathode and anode gas channels were investigated.

Liu et al. [32] examined the effect of gas flow channel dimensions and operating conditions such as pressure and temperature on the efficiency of HT-PEMFCs. They used a developed mathematical model in their research. They also calculated the concentration of gas species in the electrodes through mass transfer analysis. Since their model required less computer computing, it has been used to analyze many samples with different gas flow channels and different operating conditions, and its optimal mode has been selected. Caglayan et al. [33] investigated developed a three-dimensional and isothermal modeling for an HT-PEMFC. Triple mixed serpentine flow channel single-cell with PBI membrane was applied for the model. The model was defined in steady-state, isothermal and single-phase, and simulated for different operating temperatures in the range of 100 to $180^{\circ} \mathrm{C}$. The results show that the increase in temperature has improved the performance of the fuel cell. Also, the distribution of current density at different voltages was investigated, and it was deduced that at higher operating voltages, local flow density is more uniform. Pressure drop contours and distribution of oxygen concentration along the gas flow channel were also evaluated.

Moreover, in another study [34], they improved a mathematical non-isothermal and 3D model of HT-PEMFC. The distribution of temperature and pressure along the channels and the membrane current density distribution over the entire membrane electrode active area were shown. Results were obtained for two operating voltages of 0.45 , and 0.6 volts and the results of this model were compared with the results of the isothermal model in the previous study.

In the present study, a single-channel high-temperature PEM fuel cell, condensed with PBI, is simulated in 3D. This simulation has been carried out in steady-state, isothermal and single phase.

In the current paper, the IV curve of the simulation was validated according to an experimental work. Also, a comprehensive study of the effects of essential parameters on the PEMFC performance such as operating pressure, species concentration, ionic conductivity, electrical conductivity and current density were performed, some of which such as ionic conductivity and electrical conductivity are rarely investigated in other researches. This study was generated by an interest in obtaining a general understanding of the effect of material properties on the fuel cell efficiency. The results presented are used to define the most effective material properties that should be considered in the improvement of PEMFC degradation models.

\section{Model Details and Validation}

In this study, a single-channel HT-PEMFC with a PBI membrane is modeled in three dimensions and isothermal. The schematic of the computational region, including the PBI membrane, the catalyst layers, the gas diffusion layers (GDL) and the gas flow channel, is shown in Figure 1. In this figure, the upper part of the geometry is the cathode and the lower part is the anode.

Also, the geometric and physical properties of the fuel cell for modeling and validation are summarized in Table 1. This specification is derived from the experimental study by Ubong et al. [27]. 


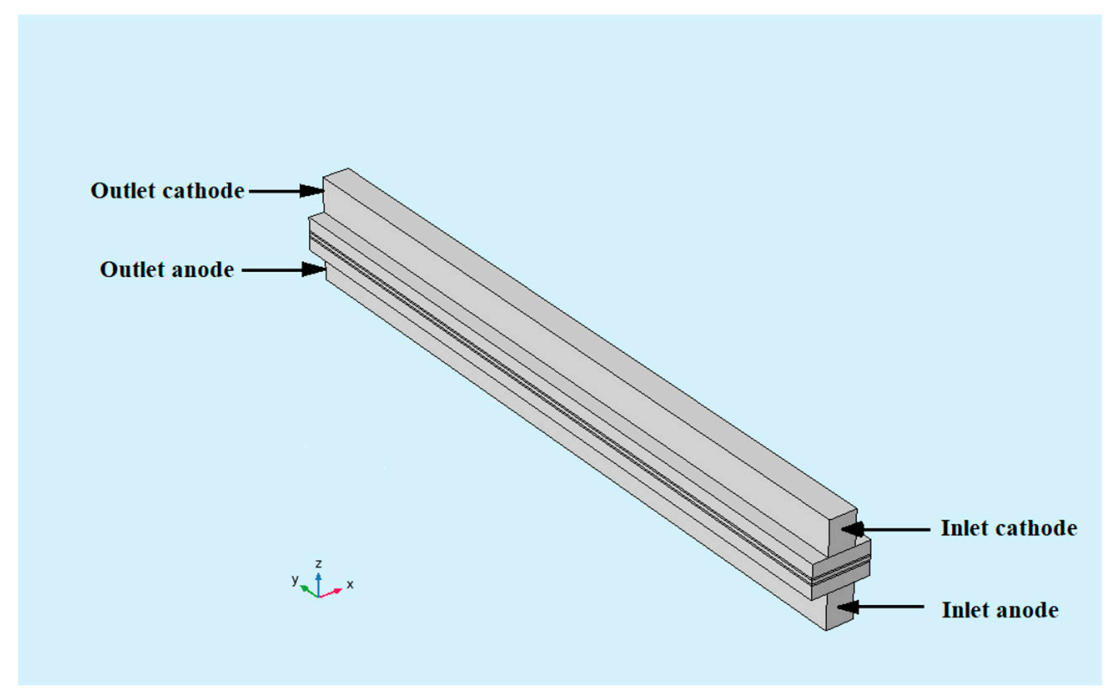

Figure 1. Schematic of 3D single-channel HT-PEMFC.

Table 1. Geometry and main physical parameters.

\begin{tabular}{ccc}
\hline Symbol & Value & Unit \\
\hline $\mathrm{h}_{\mathrm{ch}}, \mathrm{h}_{\mathrm{gdl}}, \mathrm{h}_{\mathrm{cl}}, \mathrm{h}_{\mathrm{mem}}$ & $(1,0.38,0.05,0.1) \times 10^{-3}$ & $\mathrm{~m}$ \\
$w_{c h}, w_{r i b}$ & $(0.7874,0.90932) \times 10^{-3}$ & $\mathrm{~m}$ \\
$\mathrm{~L}$ & 0.02 & $\mathrm{~m}$ \\
$\mathrm{~V}_{\mathrm{Oc}}$ & 0.93 & $\mathrm{~V}$ \\
$\varepsilon_{g d l}^{e f f}, \varepsilon_{c l}^{e f f}$ & 0.4 & - \\
$\varepsilon_{m c}$ & 0.3 & - \\
$a j_{0, a}^{r e f}$ & $1,0 \times 10^{9}$ & $\mathrm{Am}^{-3}$ \\
$a j_{0, c}^{r e f}$ & $3 \times 10^{3}$ & $\mathrm{Am}^{-3}$ \\
$\mathrm{C}_{\mathrm{H}_{2}, \mathrm{ref}}$ & 40.88 & $\mathrm{~mol} \mathrm{~m}^{-3}$ \\
$\mathrm{C}_{\mathrm{O}_{2}, \mathrm{ref}}$ & 40.88 & $\mathrm{~mol} \mathrm{~m}^{-3}$ \\
$\alpha_{a, c}$ & 1 & - \\
$\sigma_{m}$ & 9.825 & $\mathrm{Sm}^{-1}$ \\
$\sigma_{s}$ & 222 & $\mathrm{Sm}^{-1}$ \\
$D_{0, H_{2}}, D_{0, O_{2}}, D_{0, H_{2} \mathrm{O}}$ & $(9.15,2.82,2.56) \times 10^{-5}$ & $\mathrm{~m}^{2} \mathrm{~s}^{-1}$ \\
$\tau_{a, c}^{i n}$ & $100 \%$ & - \\
$k_{p}$ & $1.18 \times 10^{-11}$ & $\mathrm{~m}^{2}$ \\
$\mathrm{~F}$ & 96,487 & $\mathrm{Cmol}^{-1}$ \\
$\mathrm{R}$ & 8.314 & $\mathrm{~J} \mathrm{~mol}^{-1} \mathrm{~K}^{-1}$ \\
\hline
\end{tabular}

To test the results' independency of the mesh, nine different meshes of a structured type have been produced and the results are compared with each other. Table 2 shows the results from different meshes. To check the precision of different meshes, polarization curve is obtained for each mesh; the relative error shown in Table 2 presents the average difference of voltages achieved from numerical simulation of a sample mesh and voltages from an experimental study by Ubong et al. [27]. 
Table 2. Relative difference with benchmark solution for nine different numbers of meshes.

\begin{tabular}{cc}
\hline Number of Elements & Relative Difference with Benchmark Solution (\%) \\
\hline 104,034 & 1.06549397992631 \\
120,087 & 1.04886832015082 \\
167,684 & 1.0158217386034 \\
253,476 & 0.983903959745763 \\
583,421 & 0.940992880083474 \\
733,403 & 0.932825833514081 \\
$1,064,601$ & 0.921922105808183 \\
$1,288,763$ & 0.917297753972291 \\
$31,624,896$ & 0.88729051065396 \\
\hline
\end{tabular}

As shown in Table 2, the results are close to each other for the 1,288,763 and 31,624,896 meshes, and finally, to reduce the computational time, the mesh number has been selected 1,288,763. It is important to note that in order to get the best response, it is crucial to consider the number of meshes suitable for the GDL, the catalyst layer, and the membrane along Y. To increase the accuracy of simulation, given that the reaction occurs in the catalyst layers, the mesh of this section is finer, and a multi-grid method is used for meshing (Figure 2). The number of meshes in percent used for gas channels, GDL, catalyst layer, and the membrane are 15, 35, 45, and 5, respectively. For validation, a numerical study has been used from the experimental work of Ubong et al. [27], which is shown in Figure 3. As can be seen, there is an acceptable agreement between empirical work and numerical simulation.

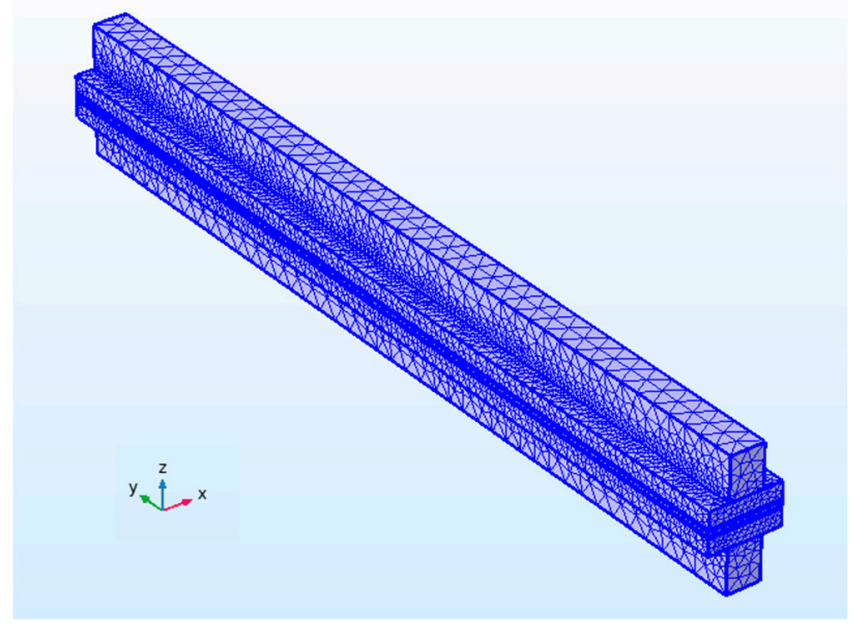

(a)

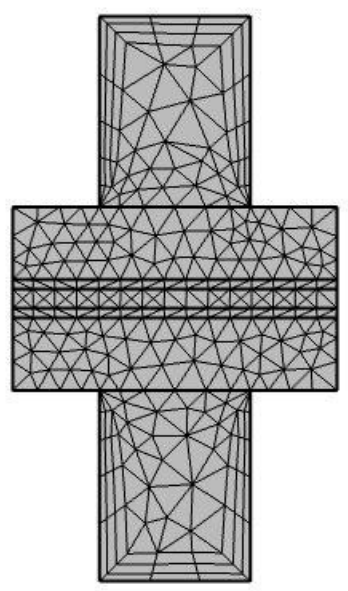

(b)

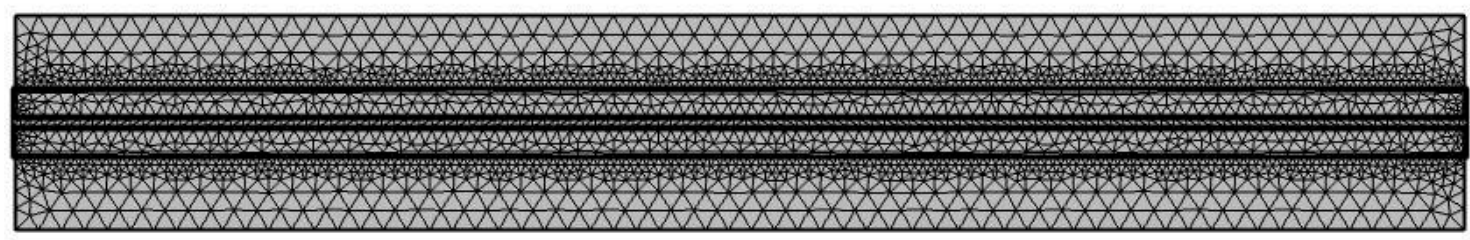

(c)

Figure 2. Multi-grid mesh for HT-PEMFC (a) isometric view, (b) right view, (c) front view. 


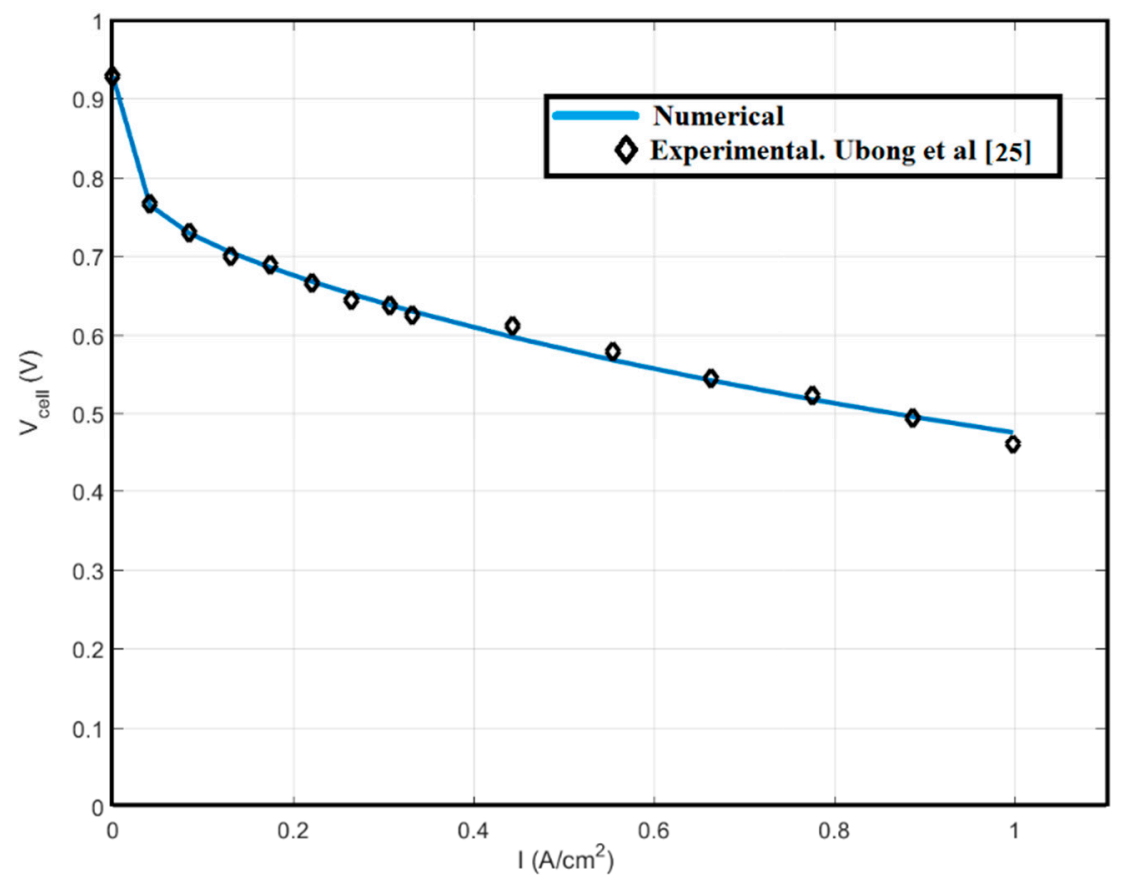

Figure 3. Comparison between the isothermal simulation at $180^{\circ} \mathrm{C}$ and experimental results.

The flow in the gas channels is laminar, and because the fuel cell works at a temperature above $100{ }^{\circ} \mathrm{C}$, water will only exist in the steam state. Also, due to the properties of PBI membrane, the water drag coefficient from anode to cathode is considered to be zero, in contrast to low-temperature PEM fuel cell with a Nafion ${ }^{\circledR}$ membrane [27]. The operating temperature of the fuel cell is $180{ }^{\circ} \mathrm{C}$ and pressure 1 bar, and stoichiometry 1.2 and 2 are considered for the anode and cathode, respectively, with a saturated inlet gas (100\% humidity). The governing equations are solved in a steady-state, and the Simple Algorithm is used to adjust the partial derivative equations. Also, the second-order upwind has been used to discrete momentum, species, and energy equations, and the first-order upwind for the discretization of charge, liquid water, and membrane water content equations.

\section{Governing Equations}

Fluid flow, heat and mass transfer, electrochemical reactions and charge transfer processes in a PEM fuel cell are described by solving the conservation equations of mass, momentum, energy, chemical species, and charge as follows.

\subsection{Mass and Momentum Conservation}

The equations of mass and momentum conservation for the PEM fuel cell are defined as follows:

$$
\begin{aligned}
& \nabla \cdot\left(\rho^{(g)} u^{(g)}\right)=S_{\text {mass }} \\
& \nabla \cdot\left(\rho^{(g)} u^{(g)}\right)=S_{\text {mass }}
\end{aligned}
$$

Source term of mass conservation equation, $S_{\text {mass }}$, is only non-zero for the catalyst layers of anode and cathode in which the mass production and consumption and the transfer of chemical species are occurred, and in the rest of the areas, it is zero. In the channels, the second term and in the porous regions where viscous forces overcome the displacement forces, the first term will be applied to the right-hand side of the momentum conservation equation. In the porous regions, the momentum 
equation of the Navier-Stokes equation is corrected to the Brinkman equation. In Equation (2), $\mu$ (pa.s) is dynamic viscosity and, $k\left(\mathrm{~m}^{2}\right)$ is permeability; $\overline{\bar{\tau}}$ is total stress tensor that is determined as follows:

$$
\overline{\bar{\tau}}=-P^{(g)} I+\mu^{(g)}\left[\nabla u^{(g)}+\left(\nabla u^{(g)}\right)^{T}\right]-\frac{2}{3} \mu^{(g)}\left(\nabla u^{(g)}\right) I
$$

\subsection{Energy Equation}

The Energy equation reads as

$$
\nabla \cdot\left(\left(\rho C_{P}\right)_{e f f} u^{(g)} T\right)=\nabla \cdot\left(k_{e f f} \nabla T\right)+S_{\text {temp }}
$$

where $C_{P}$ is the specific heat capacity of the mixture of gases, $k_{e f f}$ is effective thermal conductivity, and $T$ is temperature in Kelvin. To determine the value of the parameters in porous media, the effective characteristics are determined as follow:

$$
\begin{gathered}
\left(\rho c_{P}\right)_{e f f}=\varepsilon \rho_{f} \mathcal{c}_{P}{ }^{f}+(1-\varepsilon) \rho_{s} \mathcal{c}_{P}{ }^{S} \\
k_{e f f}=\varepsilon k_{f}+(1-\varepsilon) k_{s}
\end{gathered}
$$

In all equations, $\varepsilon$ is the porosity coefficient, which is equal to one in the gas flow channels and in the porous regions, its value ranges from zero to one. $S_{\text {temp }}$ is the source term, which includes the heat generated by the electrochemical reactions (that only exists in the catalyst layers), the Ohmic heat due to the thermal resistance of the solid areas and the heat generated by the phase change process if any.

\subsection{Equations of Species}

In chemical species equations, the consumed reactants and the products produced from the reactions are considered as gas mixtures, so they are all in the gas phase.

$$
\nabla \cdot n_{i}^{(g)}=S_{i}
$$

The source term in the transfer equation of chemical species, $S_{i}$, is zero, except for the catalyst layers where species are produced or consumed in electrochemical reactions. The source term used for the cathode and anode catalyst layers is different and depends on the exchange current density produced by the electrochemical reactions. $n_{i}^{(g)}$ is the mass flux of the type $i$ defined as follow:

$$
n_{i}^{(g)}=\rho^{(g)} u^{(g)} \omega_{i}^{(g)}-\rho^{(g)} D_{i, e f f}^{(g)} \nabla \omega_{i}^{(g)} \quad\left(i=H_{2}, O_{2}, H_{2} O, N_{2}\right)
$$

\subsection{Potential Equation of Membrane and Solid}

Transmission of electrons through the solid phase and the transport of protons through the membrane phase are expressed in terms of charge conservation equations. The transfer of protons through the membrane causes ionic flow, and transfer of electrons from the solid parts of the electrodes leads to electrical current. These equations are obtained by Ohm's law:

$$
\begin{gathered}
\text { Membrane potential : } \nabla \cdot\left(\sigma_{m} \nabla \phi_{m}\right)=S_{\text {pot }} \\
\text { Solid potential : } \nabla \cdot\left(\sigma_{s} \nabla \phi_{s}\right)=-S_{\text {pot }}
\end{gathered}
$$


where $\sigma_{s}$ and $\sigma_{m}$, respectively, are the electrical conductivity coefficient in the solid phase and the ionic conductivity coefficient in the polymer membrane. $\varphi_{s}$ and $\varphi_{\mathrm{m}}$ also indicate the potential of the solid phase and the potential of the polymer membrane phase. The source term $S_{\text {pot }}$ is defined as:

$$
S_{\text {pot }}=\left\{\begin{array}{cl}
-J_{c} & \text { (cathode cl) } \\
J_{a} & \text { (anode cl) } \\
0 & \text { (elsewhere })
\end{array}\right.
$$

In theory, the activation losses, $\eta$, which are the difference between the potentials of the solid phase and membrane, are the driving force of the volumetric exchange current density. The source terms for the solid phase and membrane phase represent the production of electrons and protons, which are calculated by the Butler-Volmer equations.

$$
\begin{aligned}
& j_{a}=j_{a}^{r e f}\left(\frac{C_{H_{2}}}{C_{H_{2}}^{r e f}}\right)^{\gamma_{a n}}\left(\exp \left(\frac{\alpha_{a} F \eta_{a}}{R T}\right)-\exp \left(-\frac{\alpha_{c} F \eta_{a}}{R T}\right)\right) \\
& j_{c}=j_{c}^{r e f}\left(\frac{C_{O_{2}}}{C_{\mathrm{O}_{2}}^{r e f}}\right)^{\gamma_{c a t}}\left(\exp \left(-\frac{\alpha_{c} F \eta_{c}}{R T}\right)-\exp \left(\frac{\alpha_{a} F \eta_{c}}{R T}\right)\right)
\end{aligned}
$$

The source terms of the conservation of electrical load are named as the transitional electrical current density. $j_{a}^{r e f}$ and $j_{c}$ ref , respectively, are the exchange current density in in the anode and cathode at reference conditions. $F$ is Faraday's constant, and $C_{i}$ and $C_{i}^{\text {ref }}$, are the concentration of chemical species and the concentration of chemical species at reference conditions, respectively. $\gamma$ is a factor dependent on the concentration and $\alpha$ is the transfer coefficient.

The activation losses, $\eta$, in the anode and cathode are calculated as follows:

$$
\begin{gathered}
\eta_{a}=\phi_{s}-\phi_{m} \\
\eta_{c}=\phi_{s}-\phi_{m}-V_{o c}
\end{gathered}
$$

$V_{o c}$ is open circuit voltage on the cathode side. Based on the charge conservation, the total electrons flowing out of the anode catalyst layer should be equivalent to the total current entered into the cathode catalyst layer, and also for the protons.

\subsection{Boundary Conditions}

The input velocities, temperature, and mass fraction of chemical species are determined as fuel cell performance parameters. Before solving the governing equations, the average electric current density, stoichiometric ratio, temperature, pressure and other parameters, the mass flow rate of the flow channels and the mass fraction of the chemical species are calculated.

For the anode and cathode gas channel, the output boundary condition is as follows.

$$
P=P_{r e f}, \frac{\partial \vec{V}}{\partial n}=0, \frac{\partial T}{\partial n}=0, \frac{\partial Y_{i}}{\partial n}=0, \frac{\partial s}{\partial n}=0
$$

All outer plates of the PEM fuel cell, except terminals, are defined as the outer boundaries of the fuel cell. The terminals are the upper and lower plates of the fuel cell that the electric current enters and exits. The flow conditions of zero flow are considered for external boundaries.

$$
\frac{\partial \phi_{s}}{\partial n}=0, \frac{\partial \phi_{m}}{\partial n}=0
$$

If the voltage is considered constant for calculating the electrical current, the following applies: 
Boundary conditions for anode terminal:

$$
\phi_{s}=0, \frac{\partial \phi_{m}}{\partial n}=0
$$

And boundary conditions for the cathode terminal:

$$
\phi_{s}=V_{\text {cell }}, \frac{\partial \phi_{m}}{\partial n}=0
$$

\section{Results and Discussion}

In Figure 4, the pressure variation in the anode and cathode sides of the fuel cell is displayed. The pressure drop across the anode channel is 2 bars, and throughout the cathode channel is higher than 9 bars. Although the pressure has decreased both in the cathode and anode, the pressure drop in the cathode is larger than the anode. Since the oxygen velocity in the inlet of the cathode channel is 2.5 times the speed of the hydrogen velocity in the input of the anode channel, a higher pressure drop in the cathode is obtained.

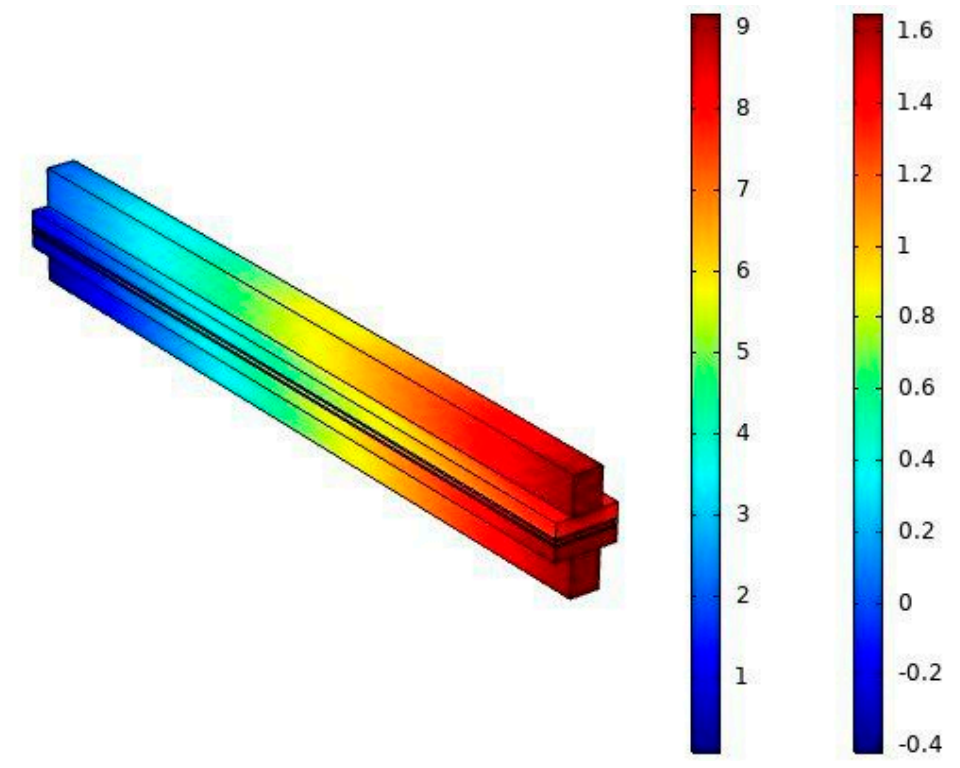

Figure 4. Pressure distribution at the cathode and anode channels at $\mathrm{T}=180{ }^{\circ} \mathrm{C}, \mathrm{P}=1 \mathrm{~atm}, \mathrm{st} \mathrm{a}_{\mathrm{a}}=1.2$, $\mathrm{st}_{\mathrm{c}}=2$ and $\mathrm{V}=0.4 \mathrm{~V}$.

Figure 5 shows the effect of pressure changes on the performance of the fuel cell. In this graph, 5 different operating pressures were investigated. According to the figure, with increasing pressure, the performance of the fuel cell is improved and the fuel cell generated power is increased; at different pressures and at a constant voltage, an increase in the fuel cell generated current can be detected, as the pressure increases, penetration of the reactive gases in the catalyst layer is augmented, which leads to an increment in the flow density. 


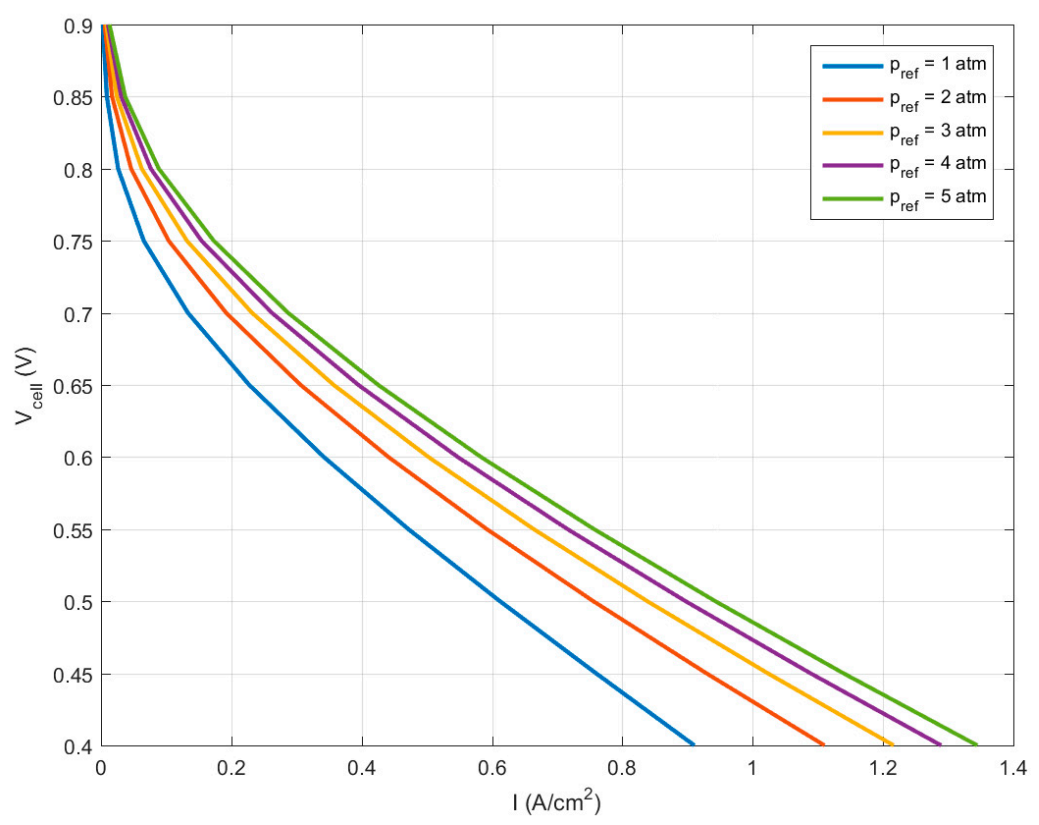

Figure 5. Pressure effect on the current density at $\mathrm{T}=180^{\circ} \mathrm{C}, \mathrm{st}_{\mathrm{a}}=1.2, \mathrm{st}_{\mathrm{c}}=2$.

The concentration of reactive species, namely, hydrogen (Figure 6a) and oxygen (Figure 6b), are shown in Figure 6 at $180^{\circ} \mathrm{C}$ and at a voltage of $0.4 \mathrm{~V}$. As can be seen, the highest concentration is at the channel entrance, and the concentration of species decreases towards the channel outlet, as the species entering the anode and cathode channel, the reaction is started and species are consumed to generate current density According to figure, the oxygen concentration along the cathode channel reached from 1.26 to $5.43 \mathrm{~mol} / \mathrm{m}^{3}$ and the hydrogen concentration along the anode channel reached from 25.8 to $25.2 \mathrm{~mol} / \mathrm{m}^{3}$ that indicating a higher concentration of oxygen comparing to hydrogen.

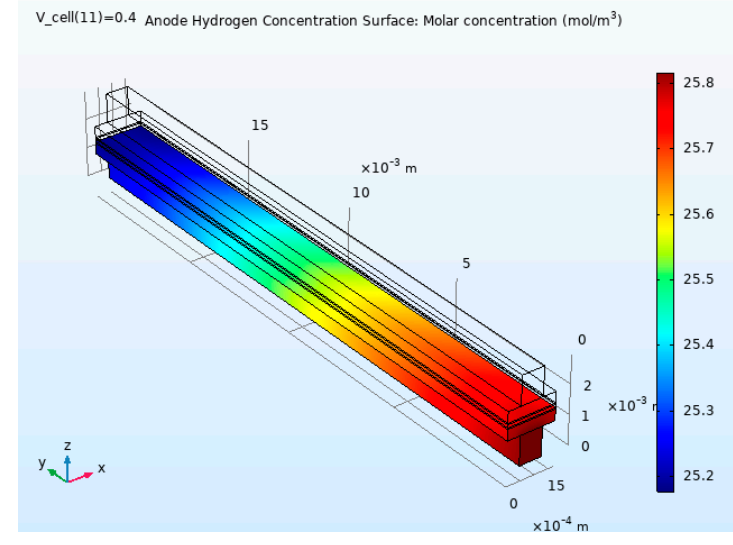

(a)

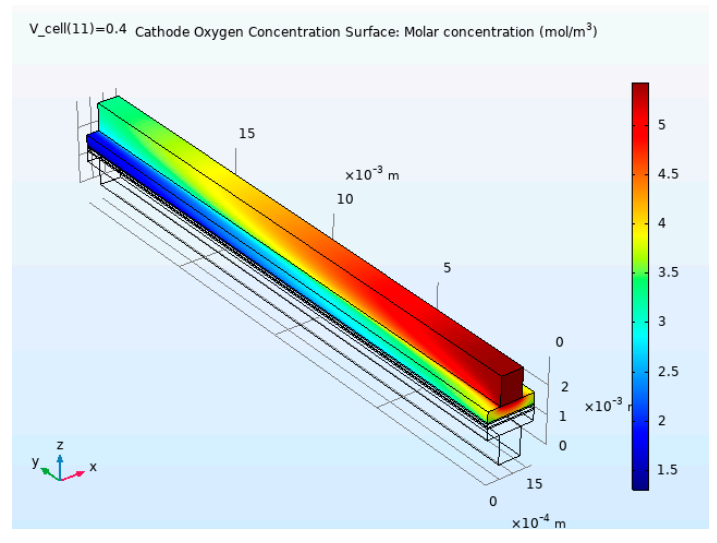

(b)

Figure 6. Concentration of (a) the hydrogen along the anode flow channel and (b) the oxygen along the cathode flow channel operating at $180{ }^{\circ} \mathrm{C}$ and $0.4 \mathrm{~V}\left(\mathrm{~mol} / \mathrm{m}^{3}\right)$.

In Figure 7, the distribution of water concentration in the anode (Figure 7a) and cathode (Figure 7b) is shown at $180^{\circ} \mathrm{C}$ and at a voltage of $0.4 \mathrm{~V}$. Regarding the figure, it can be seen that the behavior of water dispersion in the cathode and anode channels is different from the dispersion behavior of the species concentration according to Figure 6. In contrast to species concentration, the lowest concentration of water is observed at the entrance of the channels, and the highest concentration of water is observed in the channel outputs. Because with moving of reactants from the entrance to the outlet, the species is consumed and more water will be generated by the reactions. Water management in fuel cell is critical, 
so that a substantial decrease in humidity content of the inlet gas causes the membrane to dry and its ionic conduction decreases and, as a result, decreases its performance; in contrast with an excessive increase of the water level in the fuel cell, water droplets create a critical condition that blocks the pores of the porous layers and subsequently prevents the transfer of reactive gases.

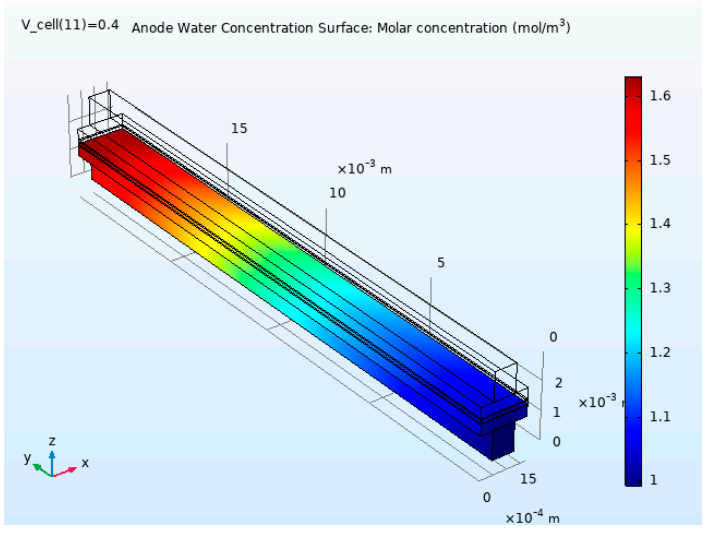

(a)

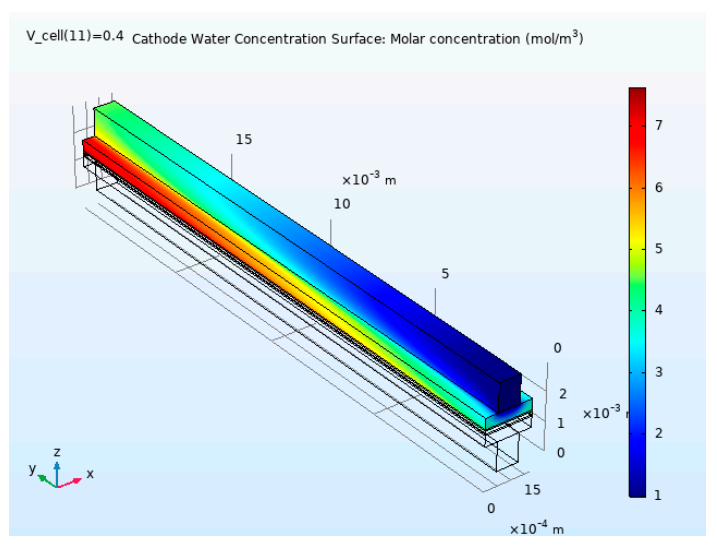

(b)

Figure 7. Concentration of water along (a) the anode flow channel and (b) the cathode flow channel operating at $180{ }^{\circ} \mathrm{C}$ and $0.4 \mathrm{~V}\left(\mathrm{~mol} / \mathrm{m}^{3}\right)$.

The effect of porosity coefficient of the GDL at $180{ }^{\circ} \mathrm{C}$ is shown in Figure 8 . This graph is depicted for three porosity coefficients of $0.3,0.4$, and 0.5 . According to this figure, the porosity coefficient has its most impact on the performance of the fuel cell at low voltages, which, with its increase, the fuel cell generated power will be enhanced. But at high voltages, there is no noticeable change, as the species consumption rate is lower at high voltages.

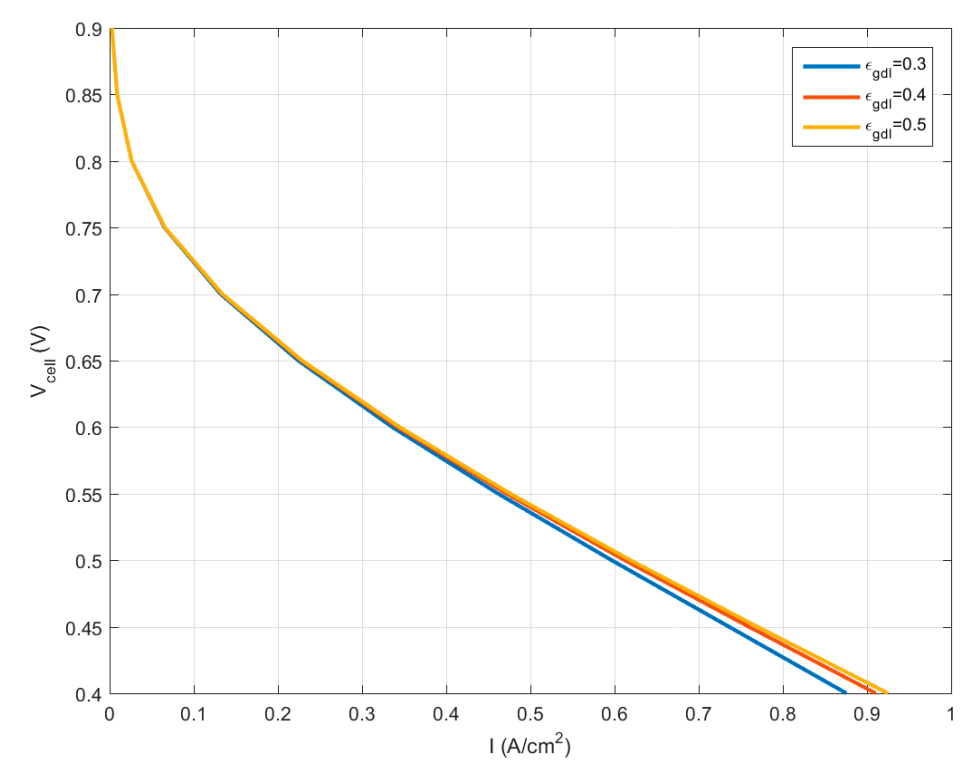

Figure 8. Effect of GDL porosity on the HT-PEMFC performance at $180^{\circ} \mathrm{C}$.

Figure 9 shows the effect of the GDL electrical conductivity coefficient and the membrane ionic conductivity coefficient at $180^{\circ} \mathrm{C}$. According to the figure, with the increase of these two coefficients, the fuel cell performance is significantly improved. As the electrical conductivity coefficient increases, the quantity of electrons transfer is increased through the solid parts of fuel cell and increasing the ionic conductivity coefficient of the membrane will increase the amount of proton transfer by the membrane 
from the anode side to the cathode side. As can be seen in the figure, the more significant effect of ionic conductivity coefficient is evident compared to the electrical conductivity coefficient.

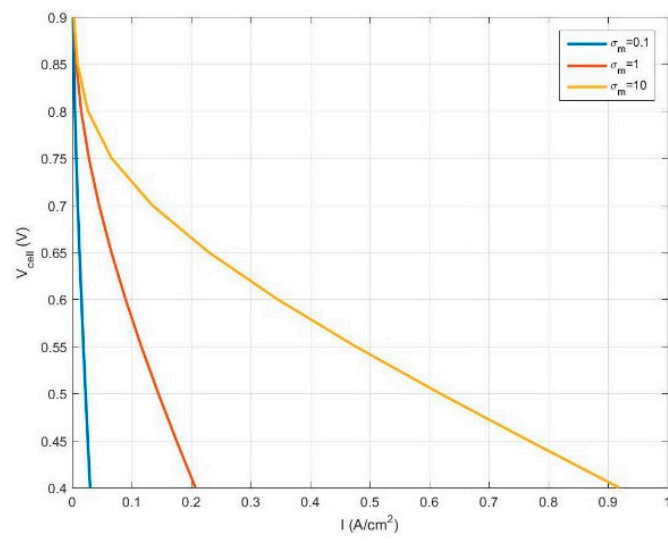

(a)

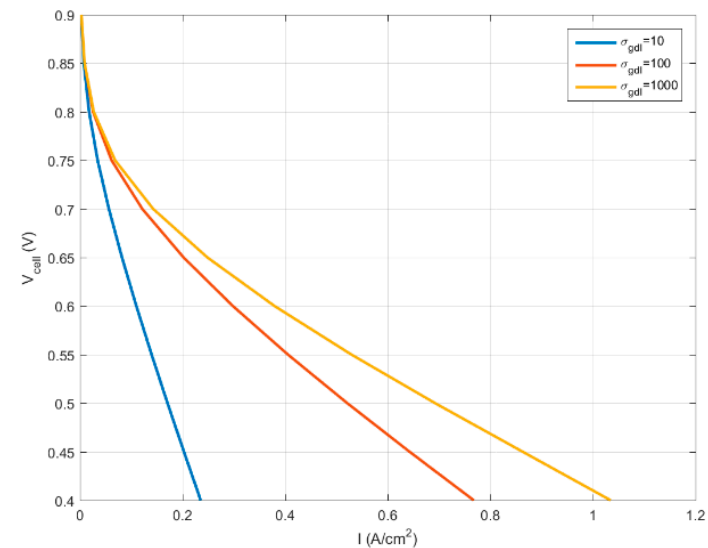

(b)

Figure 9. Effect of (a) ionic and (b) electric conductivity on the HT-PEMFC performance at $180^{\circ} \mathrm{C}$.

In Figure 10, the effect of channel width increment on fuel cell performance is shown. Based on this figure, with increasing channel width, the fuel cell generated power is reduced; as the channel width increases, the inlet velocity of the species decreases, and as a result, the diffusion rate of species will also decrease. The result will be a lower current density generation in the fuel cell.

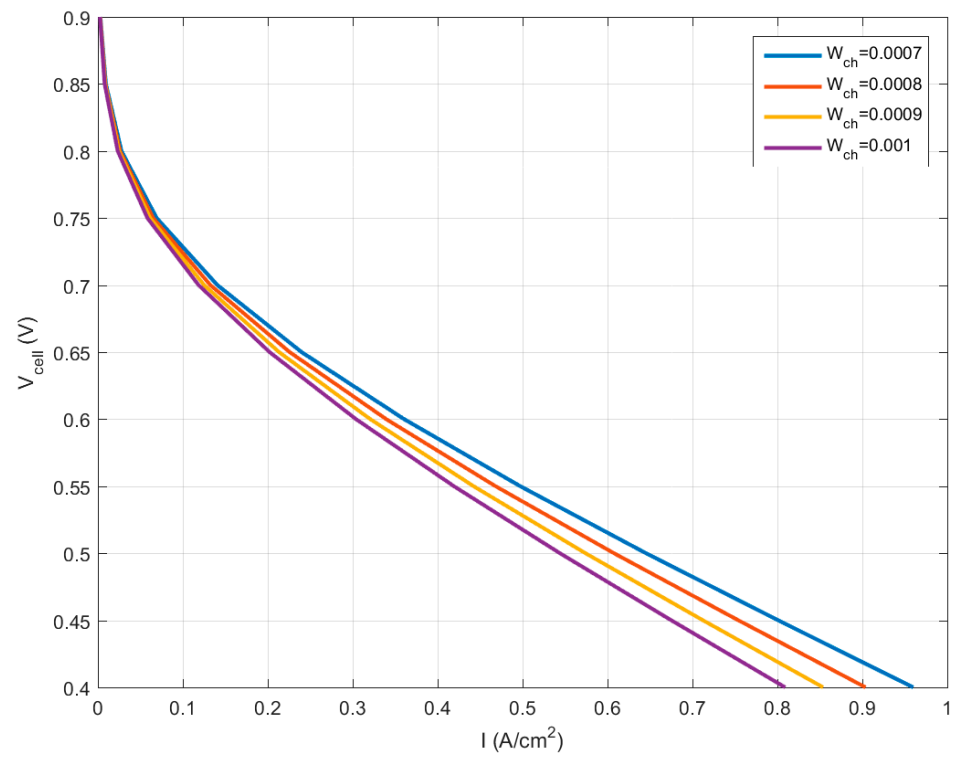

Figure 10. Effect of channel width on the HT-PEMFC performance.

Figure 11 shows the dispersion of the current density generated by the fuel cell at $180{ }^{\circ} \mathrm{C}$ and $0.3,0.6$, and $0.9 \mathrm{~V}$ at the membrane surface. As can be seen, at low voltages of 0.3 and $0.6 \mathrm{~V}$, due to the higher input inflow of the species, they penetrate into the reaction spot more and also more species participate in the reaction so that according to the figure, the difference in the amount of current density produced at high and low voltages is quite evident. Therefore, at the channel inlet, the produced current density is lower and this value increases towards the channel output as more and more reactants are consumed (Figure 11a,b). On the contrary, as the voltage increased to $0.9 \mathrm{~V}$, the produced current density decreased, because at higher voltages, due to the lower input flow rate, the species flowed with less velocity and penetration and almost uniformly along the channel and 
followed by less reaction, the current density is reduced and the distribution of the current density is almost uniform from the inlet to the outlet (Figure 11c).

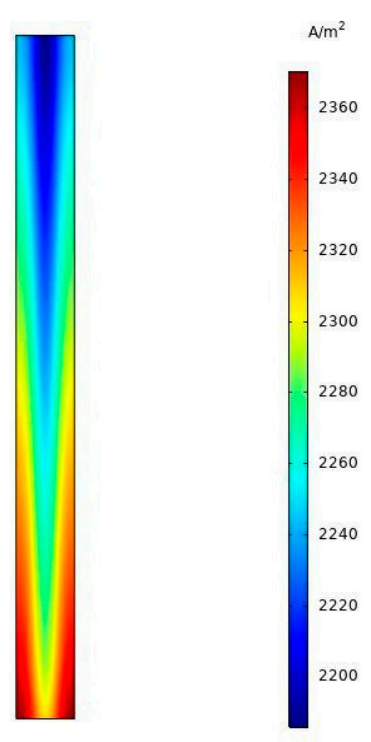

(a)

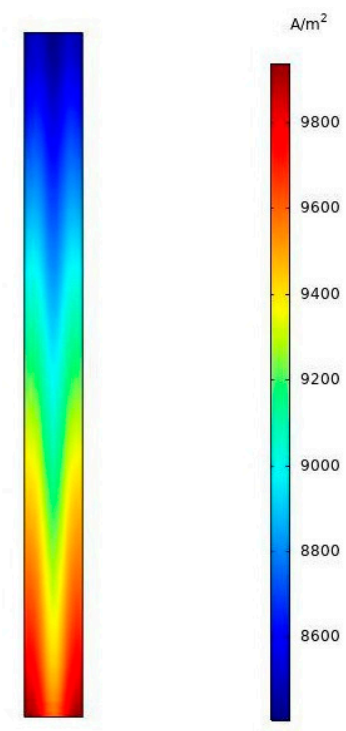

(b)

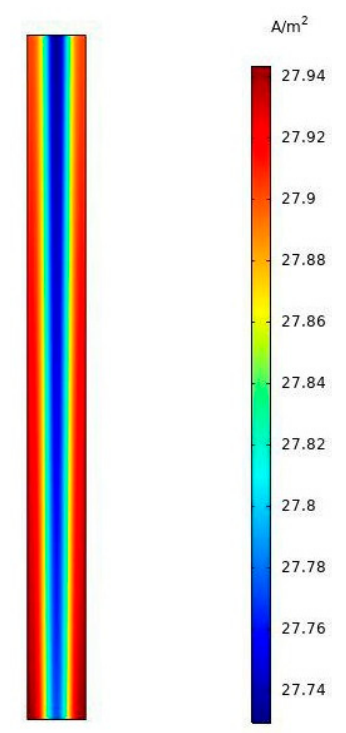

(c)

Figure 11. Current density distribution on membrane surface at $180^{\circ} \mathrm{C}$ and (a) $0.3 \mathrm{~V}$, (b) $0.6 \mathrm{~V}$, (c) $0.9 \mathrm{~V}$.

\section{Conclusions}

In this research, a single-channel high-temperature PEM fuel cell was simulated in a three dimensional, isothermal and steady-state, and the effect of different parameters on its performance was investigated. Initially, the distribution of pressure was shown in the cathode and anode channels, and it was observed that the pressure drop in the cathode channel is higher than the anode channel, so that the pressure drop in the cathode channel was 9 bars but in the anode channel was 2 bars. In the next step, the distribution of hydrogen concentration in the anode channel and oxygen concentration in the cathode channel was illustrated. The concentration of these species at the channel entrance was at its highest level and decreased with moving toward the outlet and consumption of the species. By checking the concentration of water in the channels, it was observed that the concentration of water was increased from the entrance to the outlet due to the use of species. Also, the results showed that by increasing the operating pressure, the electrical conductivity of the GDL and the membrane ionic conductivity were improved. This improvement has also been observed with increasing the GDL porosity but only at low voltages. By studying the thickness variation in the gas channel, it was also observed that its increase would reduce the performance of the fuel cell, as the increase in the inlet gas cross-section reduced the rate of the species and produced less current.

Author Contributions: Data curation, Investigation, Visualization, M.Y.A.J.; Formal analysis, Investigation, M.G.; Formal analysis, Writing-original draft, R.A.; Methodology, review \& editing, E.A.; review \& editing, S.W.; review \& editing, M.M.R.; Supervision, M.S.S.

Funding: This research received no external funding.

Conflicts of Interest: The authors declare no conflict of interest! 


\section{Nomenclature}

\begin{tabular}{|c|c|c|c|}
\hline$\alpha$ & $\begin{array}{l}\text { Specific Surface Area on the } \\
\text { Anode, } \mathrm{m}^{-1}\end{array}$ & $\overline{\bar{\tau}}$ & Total Stress Tensor, $\mathbf{N m}^{-2}$ \\
\hline$C_{\mathbf{P}}^{(g)}$ & $\begin{array}{l}\text { specific heat capacity of the gas } \\
\text { mixture, } \mathrm{JJKg}^{-1} \mathrm{~K}^{-1}\end{array}$ & $\sigma_{S}$ & electric conductivity, $\mathrm{sm}^{-1}$ \\
\hline$C_{i, \text { ref }}$ & $\begin{array}{l}\text { reference molar concentration of } \\
\text { species } \mathrm{i}, \mathrm{mol} \mathrm{m}^{-3}\end{array}$ & $\sigma_{m}$ & ionic conductivity, $\mathrm{sm}^{-1}$ \\
\hline $\mathbf{D}_{\mathbf{i}}^{(\mathrm{g})}$ & $\begin{array}{l}\text { diffusivity of species diffusivity of } \\
\text { species } i, \mathrm{~m}^{2} \mathrm{~s}^{-1}\end{array}$ & $\phi_{m}$ & ionic phase potential, $\mathrm{V}$ \\
\hline $\mathbf{D}_{\mathbf{H}_{2} \mathbf{O}}^{(\mathbf{m})}$ & $\begin{array}{l}\text { diffusivity of water in the } \\
\text { membrane, } \mathrm{m}^{2} \mathrm{~s}^{-1}\end{array}$ & $\phi_{s}$ & solid-phase potential, $\mathrm{V}$ \\
\hline $\mathrm{F}$ & Faraday's constant, $\mathrm{C} \mathrm{mol}{ }^{-1}$ & \multicolumn{2}{|c|}{ Superscripts } \\
\hline $\mathrm{h}$ & Height, $\mathrm{m}$ & eff & effective \\
\hline j & Exchange current density, $\mathrm{Am}^{-2}$ & $(\mathrm{~g})$ & gas phase \\
\hline $\mathrm{k}$ & thermal conductivity, $\mathrm{Wm}^{-1} \mathrm{~K}^{-1}$ & $(\mathrm{~m})$ & membrane \\
\hline$k_{p}$ & GDL permeability & ref & reference \\
\hline $\mathrm{L}$ & Length, $\mathrm{m}$ & $(\mathrm{s})$ & solid \\
\hline mem & membrane & \multicolumn{2}{|c|}{ Subscripts } \\
\hline $\mathbf{n}_{\mathbf{i}}^{(g)}$ & mass flux of species i, $\mathrm{kg} \mathrm{m}^{-2} \mathrm{~s}^{-1}$ & $a$ & anode \\
\hline $\mathbf{P}^{(\mathrm{g})}$ & Absolute gas pressure, $\mathrm{Pa}$ & $\mathrm{c}$ & cathode \\
\hline $\mathrm{R}$ & Universal gas constant, $\mathrm{J} \mathrm{mol}^{-1} \mathrm{~K}^{-1}$ & $\mathrm{ch}$ & Channel \\
\hline $\mathrm{s}$ & liquid saturation & $\mathrm{cl}$ & catalyst layer \\
\hline S & source term & GDL & gas diffusion layer \\
\hline St & stoichiometry & $\mathrm{H}_{2}$ & hydrogen \\
\hline $\mathrm{T}$ & temperature, $\mathrm{K}$ & $\mathrm{H}_{2} \mathrm{O}$ & water \\
\hline $\mathrm{u}, \mathrm{v}, \mathrm{w}, \mathrm{U}$ & Velocities, $\mathrm{ms}^{-1}$ & $\mathrm{i}$ & species i \\
\hline$x, y, z$ & coordinates, $\mathrm{m}$ & $\mathrm{m}$ & membrane \\
\hline$\omega_{\mathrm{i}}^{(\mathrm{g})}$ & mass fraction of species $\mathrm{i}$ & mass & mass \\
\hline$\alpha$ & transfer coefficients & $\mathrm{O}_{2}$ & oxygen \\
\hline$\zeta$ & relative humidity, $\%$ & OC & Open cirqute \\
\hline Greek & & pot & potential \\
\hline$\varepsilon$ & porosity & ref & reference \\
\hline$\varepsilon_{\mathrm{mc}}$ & $\begin{array}{l}\text { Volume fraction of ionomer in } \\
\text { anode/cathode catalyst layers }\end{array}$ & rib & rib \\
\hline$\mu$ & dynamic viscosity, $\mathrm{kg} \mathrm{m}^{2} \mathrm{~s}^{-1}$ & temp & temperature \\
\hline 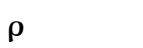 & density, $\mathrm{kgm}^{-3}$ & & \\
\hline
\end{tabular}

\section{References}

1. Alamian, R.; Shafaghat, R.; Safaei, M.R. Multi-objective optimization of a pitch point absorber wave energy converter. Water 2019, 11, 969. [CrossRef]

2. Alamian, R.; Shafaghat, R.; Shadloo, M.S.; Bayani, R.; Amouei, A.H. An empirical evaluation of the sea depth effects for various wave characteristics on the performance of a point absorber wave energy converter. Ocean Eng. 2017, 137, 13-21. [CrossRef]

3. Zanous, S.P.; Shafaghat, R.; Alamian, R.; Shadloo, M.S.; Khosravi, M. Feasibility study of wave energy harvesting along the southern coast and islands of Iran. Renew. Energy 2019, 135, 502-514. [CrossRef]

4. Ebrahimpour, M.; Shafaghat, R.; Alamian, R.; Safdari Shadloo, M. Numerical Investigation of the Savonius Vertical Axis Wind Turbine and Evaluation of the Effect of the Overlap Parameter in Both Horizontal and Vertical Directions on Its Performance. Symmetry 2019, 11, 821. [CrossRef]

5. Wang, A.; Hu, K.; Liu, Y.; Li, R.; Ye, C.; Yi, Z.; Yan, K. Flower-like MoS2 with stepped edge structure efficient for electrocatalysis of hydrogen and oxygen evolution. Int. J. Hydrog. Energy 2019, 44, 6573-6581. [CrossRef]

6. Wang, Y.; Deng, H.; Ye, C.; Hu, K.; Yan, K. Facile synthesis of mesoporous TiC-C nanocomposite microsphere efficient for hydrogen evolution. J. Alloy. Compd. 2019, 775, 348-352. [CrossRef] 
7. Hu, K.; Zhou, J.; Yi, Z.; Ye, C.; Dong, H.; Yan, K. Facile synthesis of mesoporous WS2 for water oxidation. Appl. Surf. Sci. 2019, 465, 351-356. [CrossRef]

8. Barbir, F. Pem Fuel Cells: Theory and Practice; Academic Press: Cambridge, MA, USA, 2012.

9. Manoharan, Y.; Hosseini, S.E.; Butler, B.; Alzhahrani, H.; Senior, B.T.F.; Ashuri, T.; Krohn, J. Hydrogen Fuel Cell Vehicles; Current Status and Future Prospect. Appl. Sci. 2019, 9, 2296. [CrossRef]

10. Rafique, M.K.; Khan, S.U.; Saeed Uz Zaman, M.; Mehmood, K.K.; Haider, Z.M.; Bukhari, S.B.A.; Kim, C.-H. An Intelligent Hybrid Energy Management System for a Smart House Considering Bidirectional Power Flow and Various EV Charging Techniques. Appl. Sci. 2019, 9, 1658. [CrossRef]

11. Atyabi, S.A.; Afshari, E.; Wongwises, S.; Yan, W.-M.; Hadjadj, A.; Shadloo, M.S. Effects of assembly pressure on PEM fuel cell performance by taking into accounts electrical and thermal contact resistances. Energy 2019, 179, 490-501. [CrossRef]

12. Latorrata, S.; Gallo Stampino, P.; Cristiani, C.; Dotelli, G. Development of an optimal gas diffusion medium for polymer electrolyte membrane fuel cells and assessment of its degradation mechanisms. Int. J. Hydrog. Energy 2015, 40, 14596-14608. [CrossRef]

13. Latorrata, S.; Stampino, P.G.; Cristiani, C.; Dotelli, G. Preparation, ex situ and in situ Characterization of Gas Diffusion Media Containing and Non-Containing Carboxymethylcellulose for PEM Fuel Cells. Fuel Cells 2015, 15, 463-471. [CrossRef]

14. Toghyani, S.; Afshari, E.; Baniasadi, E.; Shadloo, M. Energy and exergy analyses of a nanofluid based solar cooling and hydrogen production combined system. Renew. Energy 2019, 141, 1013-1025. [CrossRef]

15. Toghyani, S.; Fakhradini, S.; Afshari, E.; Baniasadi, E.; Jamalabadi, M.Y.A.; Shadloo, M.S. Optimization of operating parameters of a polymer exchange membrane electrolyzer. Int. J. Hydrog. Energy 2019, 44, 6403-6414. [CrossRef]

16. Authayanun, S.; Im-Orb, K.; Arpornwichanop, A. A review of the development of high temperature proton exchange membrane fuel cells. Chin. J. Catal. 2015, 36, 473-483. [CrossRef]

17. Rosli, R.; Sulong, A.B.; Daud, W.R.W.; Zulkifley, M.A.; Husaini, T.; Rosli, M.I.; Majlan, E.; Haque, M. A review of high-temperature proton exchange membrane fuel cell (HT-PEMFC) system. Int. J. Hydrog. Energy 2017, 42, 9293-9314. [CrossRef]

18. Wang, L.; Husar, A.; Zhou, T.; Liu, H. A parametric study of PEM fuel cell performances. Int. J. Hydrog. Energy 2003, 28, 1263-1272. [CrossRef]

19. Cheddie, D.; Munroe, N. Mathematical model of a PEMFC using a PBI membrane. Energy Convers. Manag. 2006, 47, 1490-1504. [CrossRef]

20. Scott, K.; Pilditch, S.; Mamlouk, M. Modelling and experimental validation of a high temperature polymer electrolyte fuel cell. J. Appl. Electrochem. 2007, 37, 1245-1259. [CrossRef]

21. Olapade, P.O.; Meyers, J.P.; Borup, R.L.; Mukundan, R. Parametric study of the morphological proprieties of HT-PEMFC components for effective membrane hydration. J. Electrochem. Soc. 2011, 158, B639-B649. [CrossRef]

22. Shamardina, O.; Kulikovsky, A.; Chertovich, A.; Khokhlov, A. A Model for High-Temperature PEM Fuel Cell: The Role of Transport in the Cathode Catalyst Layer. Fuel Cells 2012, 12, 577-582. [CrossRef]

23. Su, A.; Ferng, Y.; Hou, J.; Yu, T. Experimental and numerical investigations of the effects of PBI loading and operating temperature on a high-temperature PEMFC. Int. J. Hydrog. Energy 2012, 37, 7710-7718. [CrossRef]

24. Sun, H.; Xie, C.; Chen, H.; Almheiri, S. A numerical study on the effects of temperature and mass transfer in high temperature PEM fuel cells with ab-PBI membrane. Appl. Energy 2015, 160, 937-944. [CrossRef]

25. Al-Baghdadi, M.A.S.; Al-Janabi, H.A.S. Parametric and optimization study of a PEM fuel cell performance using three-dimensional computational fluid dynamics model. Renew. Energy 2007, 32, 1077-1101. [CrossRef]

26. Zhang, J.; Tang, Y.; Song, C.; Xia, Z.; Li, H.; Wang, H.; Zhang, J. PEM fuel cell relative humidity (RH) and its effect on performance at high temperatures. Electrochim. Acta 2008, 53, 5315-5321. [CrossRef]

27. Ubong, E.; Shi, Z.; Wang, X. Three-dimensional modeling and experimental study of a high temperature PBI-based PEM fuel cell. J. Electrochem. Soc. 2009, 156, B1276-B1282. [CrossRef]

28. Su, A.; Ferng, Y.M.; Shih, J.C. Experimentally and numerically investigating cell performance and localized characteristics for a high-temperature proton exchange membrane fuel cell. Appl. Therm. Eng. 2009, 29, 3409-3417. [CrossRef]

29. Wang, Y.; Kowal, J.; Sauer, D.U. Modeling of HTPEM Fuel Cell Start-Up Process by Using Comsol Multiphysics. In Proceedings of the 2012 Comsol Conference in Milan, Milan, Italy, 10-12 October. 
30. Liu, C.-T.; Chang, M.-H. Effects of Microporous Layer on PBI-based Proton Exchange Membrane Fuel Cell Performance. Int. J. Electrochem. Sci 2013, 8, 3687-3695.

31. Ionescu, V. High temperature PEM fuel cell steady-state transport modeling. An. Univ. "Ovidius" Constanta-Ser. Chim. 2013, 24, 55-60. [CrossRef]

32. Liu, H.; Li, P.; Hartz, A.; Wang, K. Effects of geometry/dimensions of gas flow channels and operating conditions on high-temperature PEM fuel cells. Int. J. Energy Environ. Eng. 2015, 6, 75-89. [CrossRef]

33. Caglayan, D.G.; Sezgin, B.; Devrim, Y.; Eroglu, I. Three-dimensional modeling of a high temperature polymer electrolyte membrane fuel cell at different operation temperatures. Int. J. Hydrog. Energy 2016, 41, 10060-10070. [CrossRef]

34. Caglayan, D.G.; Sezgin, B.; Devrim, Y.; Eroglu, I. Three-dimensional non-isothermal model development of high temperature PEM Fuel Cells. Int. J. Hydrog. Energy 2018, 43, 10834-10841. [CrossRef]

(C) 2019 by the authors. Licensee MDPI, Basel, Switzerland. This article is an open access article distributed under the terms and conditions of the Creative Commons Attribution (CC BY) license (http://creativecommons.org/licenses/by/4.0/). 